\title{
A BLOCKCHAIN HYPE ÉS A KÖZIGAZGATÁSI REALITÁS *
}

\author{
Budai Balázs Benjámin ${ }^{1}$
}

Napjaink egyik legizgalmasabb témája a blockchain technológia, és az arra épülö megoldások térnyerése az élet számos területén, így a közigazgatásban is. A blockchain-örület jelentöségét nem látjuk pontosan: vannak, akik nem vesznek róla - egyelöre - tudomást, és vannak, akik egy újfajta kontrollviszony alapvetö infrastrukturális elemeként definiálják. ${ }^{2}$ (A szerzö eröteljes technofil beállitottsága utóbbi irányba hajtja, azonban számos fenntartással. Ezért született ez a cikk.)

A Blockchain (vagy blokklánc) egy olyan kriptográfiai módszerekkel támogatott, decentralizált informatikai hálózat, melynek egyenrangú végpontjai közvetlenül (és hitelesítve) kommunikálnak egymással, kiemelt központi csomópont nélkül. E megoldás alapjait ún. peer-to-peer (vagy P2P) típusú hálózatok jelentették (pl.: Bittorrent, Skype). Ahogy Sík Zoltán Nándor a technológiát is alaposan bemutató tanulmányában - nagyon helyesen - rá is mutat munkájában, ${ }^{3}$ e technológia alapjaiban rengethet meg társadalmi formációkat és hierarchiákat, mert pontosan azokat a közegeket, közvetítőket és struktúrákat teszi feleslegessé, amelyek jelen társadalmunk fontos építőkövei. Miután megtizedeli a közvetítőket, az a gazdaság nagy részét adó szolgáltató szektort fenekestöl felforgathatja. Nem véletlenül hívják ezt a technológiát (is) ${ }^{4}$ web 3.0-ának, hiszen a webes tevékenységek új generációját hozzák el.

Két fö fajtáját különböztetjük meg: a publikus blokkláncot és a privát blokkláncokat. A világ jelenleg is népszerü szolgáltatásai és a fejlődés fősodra a publikus megoldásoknál látszik, azonban a legnagyobb anomáliák is itt keletkeznek.

Bár a blokklánc technológiáját eredetileg a BitCoin kriptovaluta (alternatív elszámolási eszköz) üzemeltetésére hozták létre (és jelenleg is a technológiával több, mint ezer különböző kriptovaluta - altercoin - müködik), körvonalazódnak azok a területek, amelyeket a közigazgatás használhat, hogy látványosan gyorsuljon, és transzparenssé váljon. Ezek pedig a következők:

a) „Smart contractok” (okos szerződések): Minden „ha-akkor” típusú kapcsolat programozható e technológiában, így egy feltétel teljesülése

\footnotetext{
* DOI 10.21867/KjK/2018.2.2.

${ }^{1}$ Dr. habil. Budai Balázs Benjámin, intézetvezető egyetemi docens, NKE ÁKK

${ }^{2}$ Z. Karvalics László - Nagy Gábor Dániel (2017): „Prokrusztész nélküli világ? Blokklánc és társadalmi makroevolúció”, Információs Társadalom, XVII. évf. 3. szám, 7-38 old.

3 Sík Zoltán Nándor (2017): A blockchain filozófiája, avagy a fennálló társadalmi rendek felülvizsgálatának kényszere. Új Magyar Közigazgatás, 2017/5. szám.

${ }^{4}$ Web 3.0-ának eredetileg a szemantikus webet hívták, mely az adatok újra-hasznosításán alapul.
} 
esetén a szerződésben foglalt következmény automatikusan végrehajtásra kerül (nyilván először az egyszerübb szerződéseknél). Nincs szükség ügyvédekre, nincs követeléskezelés, körbe-tartozás stb. De nincs szükség nemzeti jogra (és annak intézményeire) sem ebben az esetben, mert a világ két bármely pontja közötti megállapodás automatikusan végrehajtásra kerül a feltételek teljesülése esetén.

b) Online azonosítás, validáció: a blokklánc kriptográfiai megoldásai miatt az egyik legbiztonságosabb adattárolási és azonosítási megoldást tudja adni, így a magasabb szintü - ügyfél azonosítást kívánó szolgáltatásoknál támaszkodhatunk rá.

c) Közösségi gazdasági megoldások: a peer-to-peer technológia egy kereskedelmi értéklánc összes szereplőjét kiiktathatja az eladón és a vevőn kívül. Ez olcsóbbá és gyorsabbá teszi a kereskedést. A közbeszerzés kérdésköre is teljesen átértékelődhet.

d) Crowfounding (közösségi finanszírozás): egyre több olyan üzleti ötletet látunk, melynek pénzügyi alapjait közösségi finanszírozással próbálják megteremteni. Azaz közzé tesznek egy koncepciót, üzleti tervet stb-t, és befektetőket gyüjtenek hozzá, akik a későbbi nyereség reményében vásárolnak részesedést.

e) Szavazások: a technológia publikussága, az elosztott adatbázis technológiából fakadó átláthatóság és az online azonosítás egyszerűbbé, gyorsabbá és olcsóbbá tehet közvélemény-kutatásokat, szavazásokat. (Pl.: az ausztrál Flux nevủ alkalmazásban a szavazók dönthetnek arról, hogy képviselőjük miről szavazzon. Szavazataikat át is adhatják a hozzáértőknek.)

f) Adattárolás: A decentralizált, megosztott adattárolási rendszerek a hekkelésekkel és adatvesztéssel szemben sokkal ellenállóbbak, mint a centralizált (kliens-szerver) megoldások. Ráadásul a transzferek (streamingek) gyorsabbak is ezekben a struktúrákban.

g) Nyilvántartás: Fentiekböl következik, hogy a nyilvántartások is hatékonyan helyezhetők blokklánc alapokra. Nem véletlen, hogy Honduras, majd Svédország is bejelentette, hogy az ingatlannyilvántartását blokklánc alapokra (is) kívánja helyezni.

h) Közösségi intelligencia, okos-kormányzás, döntéstámogatás: A közösségi alapú predikciók - az egyes vélemények számossága miatt magas pontosságot érhetnek el. A döntéshozatalt eltorzító tévhitek a vélemények átlagolásával kiszürhetők.

i) IoT (Internet of Things - Dolgok internete) megoldások: A hálózatban az okos szerződések segítségével - automatizálhatók szoftverek (, illetve a szoftverek által irányított gépek, szenzorok). Ezzel magas fokú rendszerhatékonyság és költségmegtakarítás érhető el.

Mindezek pénzügyi alapjait egyelöre a kriptodevizák jelentik. A blokklánc azonban egyelőre több kérdőjelet, megoldandó feladatot rejt. A legfőbb 
problémát épp az jelenti, hogy a rendszer felett nincs joghatóság. Miután decentralizáción (központ nélküli, konszenzuson) alapuló rendszer a publikus blokklánc, nincs hatósági-felügyeleti szerv, aki egy esetleges anomáliát kezelni tudna. Nincs jogorvoslat, nincs állami kényszer sem. Amit egyszer végrehajtottak (függetlenül annak jogszerüségétől, a résztvevők eredeti akaratától), azt már nem lehet semmissé tenni. Ez pedig - jelen tudásunk szerint - aggályos. Pontosan azok a jogi garanciák hiányoznak, amitől egy jogállamban biztonságban érezheti magát egy állampolgár. A rendszer elosztott jellege miatt a joghatóság kérdése is meghatározhatatlan, így a müködés állami felügyeletét, esetleges kényszerintézkedéseinek foganatosítását nehezen tudnánk értelmezni.

Amekkora áldás, akkora probléma is a korlátozott transzparencia: előny, hogy a technológia minden tranzakciót követhetővé és eltünhetetlenné tesz. Ugyanakkor a nyilvános blokkláncban azt látjuk, hogy mi történik, azt nem, hogy kik a tranzakció résztvevői. (Ezért is kedvelt fizetési mód a BitCoin a darkweb felületeken.) Ez visszaélésekre adhat okot, valamint az államfö bevételétől foszthatja meg magát, hiszen ezek a megoldások adókikerülésre (kis jóindulattal adóoptimalizálásra) tökéletesen alkalmasak.

Ebből fakadó kihívás, hogy a pénzügyi rendszerek átláthatatlansága megkerülhetôvé teszi az adóhatóságokat. (Eladhatok bitcoin-ért egy családi házat, várok egy nagyobb árfolyam-emelkedést, és később veszek bitcoin-ért egy két másik villát, amiből az egyiket kiadom, és bitcoin-jövedelmeimből életem végéig vígan élek. Ez mind láthatatlan az adóhatóság számára, amennyiben a tranzakció során nem történik konvertálás a nemzeti valutára, azaz csak a bitcoin pénztárcámat használom. A legrosszabb, ami történhet, egy vagyonosodási vizsgálat.) Ennek kumulált következménye, hogy az állam (adó jellegü) bevételei drasztikusan megcsappanhatnak, így az állam finanszírozhatóvá válása kerül veszélybe.

Végül, a negyedik legnagyobb probléma a pénzügyi hátteret képező kriptodevizák volatilitása. Az egyes árfolyamok olyan napon belüli emelkedéseket és eséseket is el tudnak szenvedni, ami kiszámíthatatlanná teszi az ügyletek ellenértékét. (E sorok írásakor valamennyi kriptodeviza látványosan zuhan, az egy hónappal ezelőtti értékük felénél járnak.) Amíg ezek a kérdések megnyugtatóan nem rendeződnek, nem képezheti alapját domináns közigazgatási alkalmazásoknak. Ennek köszönhető, hogy az államok egyelöre ambivalensen állnak a technológiához. Vannak államok, amelyek egyik-másik részét tiltják (pl.: Kína, USA), és vannak, akik kockáztatnak és már a ráépülö megoldásokon dolgoznak (pl.: Észtország, Oroszország, Brazília, Svédország, Egyesült Arab Emirátusok stb.)

E sorok szerzője a közigazgatás számára egy privát blokklánc megoldást tart járható útnak, ahol - a blokklánc szellemiségével ellentétben - nem a lánc egyes 
szereplői alkotják a szabályokat, hanem az állam alakítja ki azt a játékteret, ahol a technológia valamennyi hozadékát egy korlátozott és felügyelt környezetben (ahol az állam, mint Trusted third party lép fel), megfelelö jogi garanciák mellett használni lehet.

\section{Források jegyzéke:}

- Sík Zoltán Nándor (2017): A blockchain filozófiája, avagy a fennálló társadalmi rendek felülvizsgálatának kényszere. Új Magyar Közigazgatás, 2017/5. szám.

- Z. Karvalics László - Nagy Gábor Dániel (2017): „Prokrusztész nélküli világ? Blokklánc és társadalmi makroevolúció”, Információs Társadalom, XVII. évf. 3. szám, 7-38 old. 